\title{
DRYING OF SQUASH USING SOLAR TUNNEL DRYER WITH PHOTOVOLTAIC
}

\author{
Derbala, A. ${ }^{1}$, Udroiu, N.A. ${ }^{2}$, Mitroi, A. ${ }^{2}$ and Iacomi, C. ${ }^{2}$
}

\section{ABSTRACT}

Experimental solar tunnel dryer (type Hohenheim $2 x 18 \mathrm{~m}$ ) with photovoltaic-module and integrated air heat collector has been installed at the department of agricultural engineering, university of agronomic sciences and veterinary medicine, Bucharest, Romania to study and evaluate the squash drying process. The obtained results indicated that, there is an inversely relation between the air relative humidity and both the air temperature and the intensity of solar radiation. The maximum difference between the drying air temperature and ambient temperature was $30^{\circ} \mathrm{C}$ afternoon $(14.20 \mathrm{~h})$ at two different thicknesses of squash slices $(0.5$ and $1 \mathrm{~cm})$. The higher rate of moisture removal was $80 \mathrm{~kg} / \mathrm{h}$ in case of $1 \mathrm{~cm}$ thick of squash slices at the first two hours. On the other hand, it was $45 \mathrm{~kg} / \mathrm{h}$ in case of $0.5 \mathrm{~cm}$ thick of squash slices at the first three hours. The potassium and phosphor ratios increased in the dried squash as compared with the fresh squash. Whilst, the nitrogen ratio decreased in thicknesses of slices and the minimum value was found with $0.5 \mathrm{~cm}$ thick. The solar tunnel dryer can be used to enhance the quality of agricultural dried crops. The production of dried crops is a promising alternative method to sale as compared with the fresh produce.

Key Words: drying, dried vegetables, solar dryer, PV-Module

\section{INTRODUCTION}

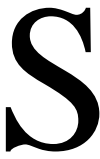
quash is considered as one of the most important vegetable crops all over the world. The annual productions of fresh squash in Egypt and Romania, are respectively 17.602 t.ha $^{-1}$ and 12.002 t.ha $^{-1}$ [FAO, 2006]. Physical properties of dried agricultural products especially fruits and vegetables are influenced by a variety of physical, enzymatic and microbiological reactions and process.

${ }^{1}$ )- Agricultural engineering dept., faculty of agriculture, Tanta University, Egypt.

${ }^{2}$ )- Agricultural engineering dept., University of agricultural sciences and veterinary medicine, Bucharest, Romania. 
Quality changes during the drying process are of a complex natural as long as several of these processes take place simultaneously [Reuss, 1993]. To reduce conductive heat losses on the backside of any kind of a heat insulating material can be used underneath the bottom of the dryer [Linchk, 1993].

The extremely low power requirement allows the use of photovoltaic for driving the fan. This enables application in remote areas where electricity from the mains is not available or not reliable [Lutz et al., 1988 and Esper and Mühlbauer, 1993]. Photovoltaic drive, solar air heater and solar dryer must act as a single unit, with mutual interaction of the single component. The drying rate is mainly influenced by the air flow rate and the corresponding temperature rise [Esper et al., 1994].

In comparison to natural sun drying the use of the solar tunnel dryer leads to a considerable reduction of the drying time and a significant improvement of the product quality in terms of colour, texture and taste of plum, [Mitroi et al., 2000]. Also, the drying tests with the solar tunnel dryer have shown that the quality of dried vegetables is greatly influenced by the method of harvesting, the maturity of the crop and the pre-treatment used [Udroiu, 2002].

Over production and diseases cause low prices for fresh harvest and increase the demand for appropriate preservation methods of the fresh squash. Focussing on a second problem besides the improvable vegetable marketing, the vitamins and health side, which is a very important. On the other hand, the source of power and electricity in new reclamation lands is scarcity. Solar thermal technology can be used to assist with the drying of such products. Solar crop drying technologies can help to improve and protect crops.

Therefore, the main objective of this experimental work was to investigate the drying behaviour of squash using solar tunnel dryer with photovoltaic.

\section{MATERIALS AND METHODS}

This experimental work was carried out at University of agronomic sciences and veterinary medicine in Romania during July and August 2008. The tunnel drier located in Bucharest city was at latitude of $44^{\circ} 50^{\prime}$, longitude of $26^{\circ} 13^{\prime}$ and altitude of $90 \mathrm{~m}$. To conduct the experiments, the following procedure was used: 


\section{Raw materials:}

Summer squash belongs to the species cucurbita pepo (family cucurbitaceae, genus- cucurbita) was used in these experiments. The squash can be yellow, green or light green colour, and generally has a similar shape to a ridged cucumber, though a few cultivars are available that produce round or bottle-shaped fruit. In a culinary context, squash is treated as a vegetable, which means it is usually cooked and dried presented as a savoury dish or accompaniment [Fig. 1 and Table1, FAO, 2006].

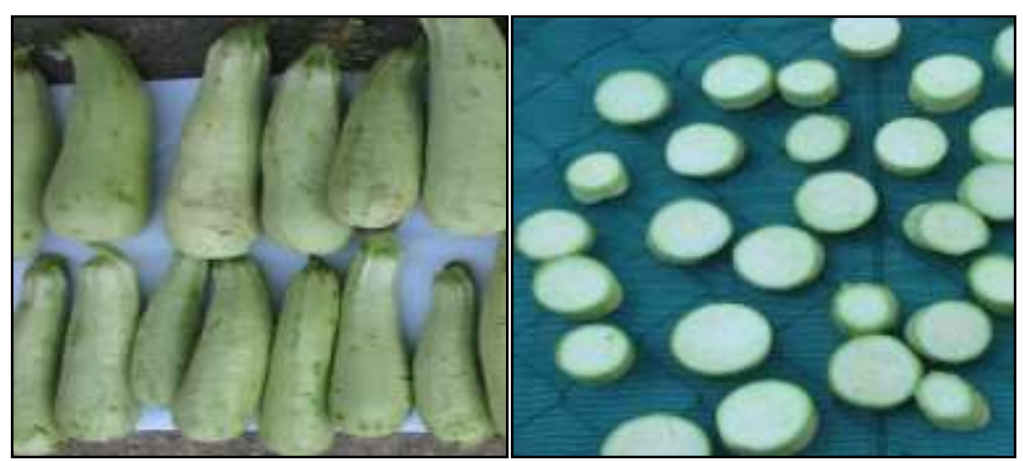

Fig. 1: Squash (Cucurbita pepo) - fresh and before drying

\section{Solar tunnel dryer:}

In solar drying processes the main source of energy for moisture removal is by the sun. There are two different ways of drying processes. First, direct solar drying, the product is directly exposed to solar radiation. The thermal energy is responsible for the moisture removal. Second, indirect solar drying, in a solar collector, when the solar radiation is converted into thermal energy and via the drying air is then transferred to the product for moisture removal.

The air flow rate necessary for proper drying depends on the product to be dried, the moisture content of the product, the available solar radiation and the dimension of the dryer. Air flow is directed underneath the solar module to lower the temperature of the solar cells, since increasing temperature of the solar cells results in lower efficiency of the solar module. During the drying process the product is completely sheltered from rain, dust, insects, birds and rodents attack.

The solar tunnel dryer is made using simple tools and locally available materials. The solar air heater and the tunnel dryer consist of an insulated 
floor and a metal frame along the sides. Both components are covered with UV-resistant transparent plastic sheet. One side of the sheet of the drying tunnel was fixed to a metal tube, allowing the sheet to be rolled up and down for loading and unloading the dryer. The floor of the solar air heater is painted in black paint or covered with heat resistant black woven fabric in order to increase the absorbed solar radiation. Both collector and drying tunnel were installed on concrete or steel structures [Figs. 2 and 3].

Table 1: Specifications and miniral analysis of fresh squash

\begin{tabular}{|c|c|c|}
\hline Squash, type-DANA & Unit & Value \\
\hline Weight & $\mathrm{g}$ & $100-250$ \\
\hline Length & $\mathrm{cm}$ & $14-29$ \\
\hline Diameter & $\mathrm{cm}$ & $3.5-8$ \\
\hline Colour & - & light green \\
\hline Form & - & bottle-shaped \\
\hline Moisture content (w.b) & $\%$ & 95.20 \\
\hline TSS & $\%$ & 4.8 \\
\hline N total & $\%$ & 3.9010 \\
\hline$(\mathrm{P})$ & $\%$ & 0.86 \\
\hline$(\mathrm{K})$ & $\%$ & 2.75 \\
\hline$(\mathrm{Ca})$ & $\%$ & 0.065 \\
\hline$(\mathrm{Mg})$ & $\%$ & 0.010 \\
\hline
\end{tabular}

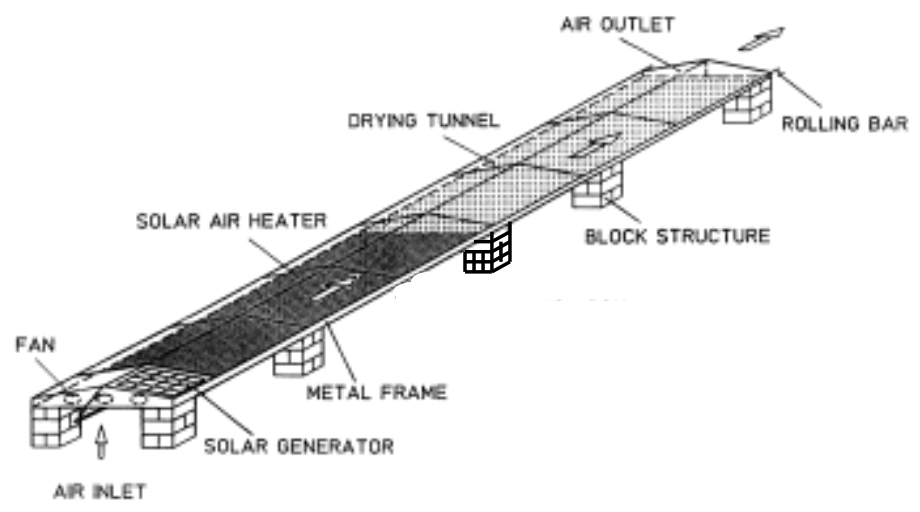

Fig. 2: Solar tunnel dryer with direct photovoltaic power supply (type Hohenheim) 
Photovoltaic drives will only be used in solar dryers, if they can complete with conventional systems with respect to repayment and capital appropriations. The main cost factor of a photovoltaic drive is still the photovoltaic system, particularly the solar modules. Size and kind of the photovoltaic system are mainly influenced by the weather conditions, the characteristic curve of the solar tunnel dryer, the efficiency of the fan, the drying product and the drying process. The technical data for the solar tunnel dryer are indicated in Table 2.

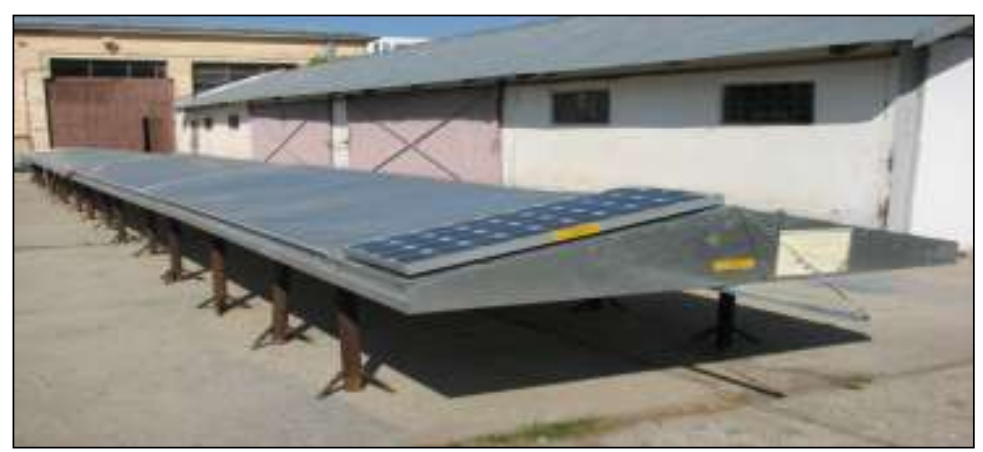

Fig. 3: Solar tunnel dryer in experimental place

Table 2: Technical data of solar tunnel dryer

\begin{tabular}{|c|c|}
\hline Parameters & Value \\
\hline Width & $2 \mathrm{~m}$ \\
\hline Length & $18 \mathrm{~m}$ \\
\hline Air flow & $400-1200 \mathrm{~m}^{3} / \mathrm{h}$ \\
\hline Air temperature & $30-80^{\circ} \mathrm{C}$ \\
\hline Thermal energy gain & up to $60 \mathrm{kWh} /$ day \\
\hline Collector area & $16 \mathrm{~m}^{2}$ \\
\hline Drying area & $20 \mathrm{~m}^{2}$ \\
\hline Energy consumption & $200 \mathrm{Wh} / \mathrm{d}$ \\
\hline Power requirement & $20-40 \mathrm{~W}$ \\
\hline
\end{tabular}

\section{Moisture content and moisture removal rate:}

The moisture content (d.b) of squash is calculated using the following mathematical formula based on the instantaneous weight changes of squash during the drying process [cited from Adam, 1998]. 
Where:

$$
X_{(t)}=\frac{m_{(t)}-m_{D}}{m_{D}}
$$

$\mathrm{X}_{(\mathrm{t})}-$ moisture content in $\mathrm{kg} / \mathrm{kg}$,

$m_{(\mathrm{t})}-$ initial mass in $\mathrm{kg}$ and

$m_{D}-$ dry matter mass in $\mathrm{kg}$.

Since the moisture removal rate during the drying period was not constant, the mean of moisture removal rate was computed using Equation 2 [cited from Häuser, 1995]:

$$
\Delta_{m}=\frac{\left(\mathrm{X}_{0}-\mathrm{X}_{1}\right) \cdot \mathrm{m}_{D}}{\Delta_{t}}
$$

$\Delta_{t}$

Where:
$\Delta_{m}$ - water removal rate in $\mathrm{kg} / \mathrm{h}$,
$\mathrm{X}_{0}$ - initial moisture content (d.b) in $\mathrm{kg} / \mathrm{kg}$,
$\mathrm{X}_{1}$ - final moisture content (d.b) in $\mathrm{kg} / \mathrm{kg}$,
$\mathrm{m}_{D}-$ dry matter mass in $\mathrm{kg}$ and
$\Delta t$ - time in $\mathrm{h}$.

Before drying, $200 \mathrm{~kg}$ fresh squash were washed using clean water, damaged or spoiled fruits were eliminated and the final product was divided in two treatments. First, squash slices with $1 \mathrm{~cm}$ thick and second, squash slices with $0.5 \mathrm{~cm}$ thick. The ambient air temperature, drying air temperature and internal product temperature were measured by thermohigrometer type Wetekom ST 2232 with PC-interface. Also, the meteorological station was utilized to obtain the weather data such as air temperature, air relative humidity and solar radiation.

\section{RESULTS AND DISCUSSION}

\section{Entering air characteristics:}

The air temperature, air relative humidity and the solar radiation are very important parameters in solar drying. The temperature of the drying air is automatically controlled according to the intensity of solar radiation. During periods of low radiation the air flow rate is also reduced leading to a comparatively high temperature rise. High radiation causes a higher air flow rate which results in a comparatively lower temperature rise. Figs. 4 and 5 reveal the relationship between the entering air temperature, air 
relative humidity and the solar radiation. As anticipated the higher air temperature and the lower relative humidity at the higher solar radiation, then the lower was the final moisture content.

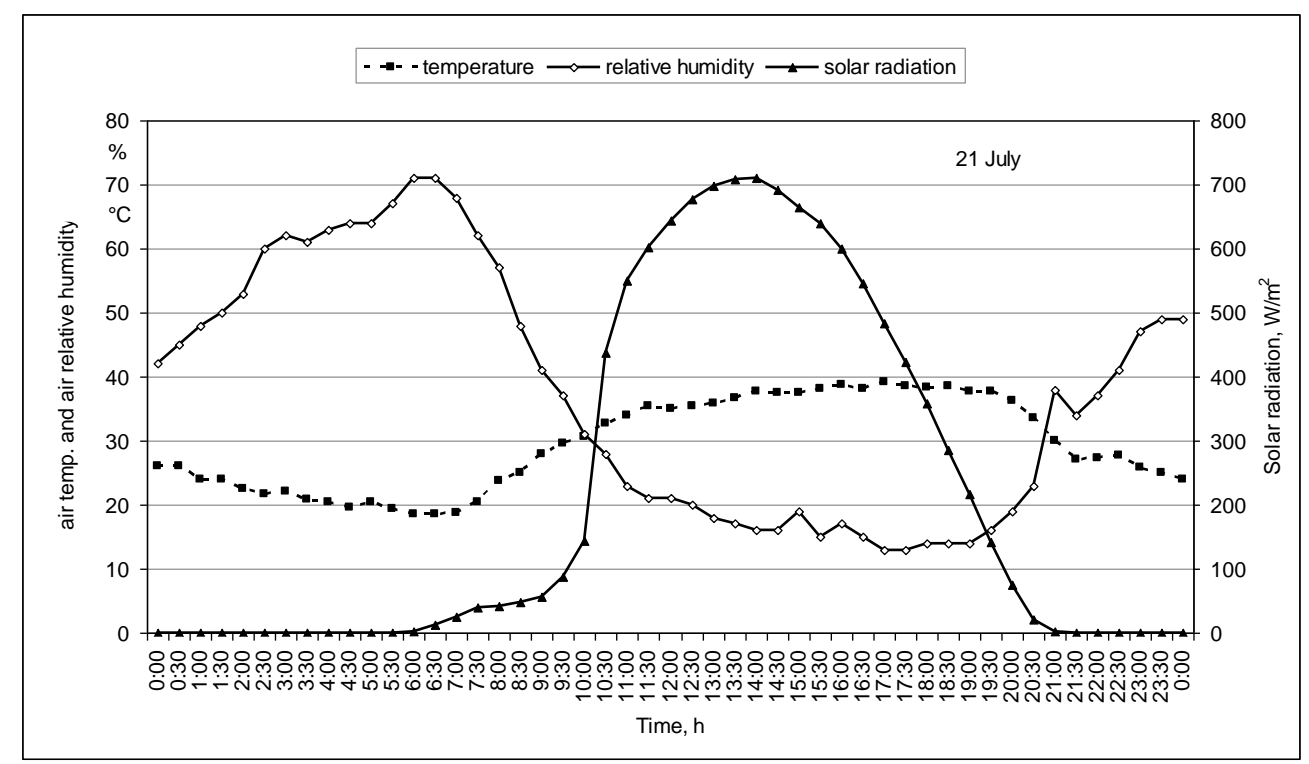

Fig. 4: The air temperature, air relative humidity and solar radiation during the period of experiments (21 July)

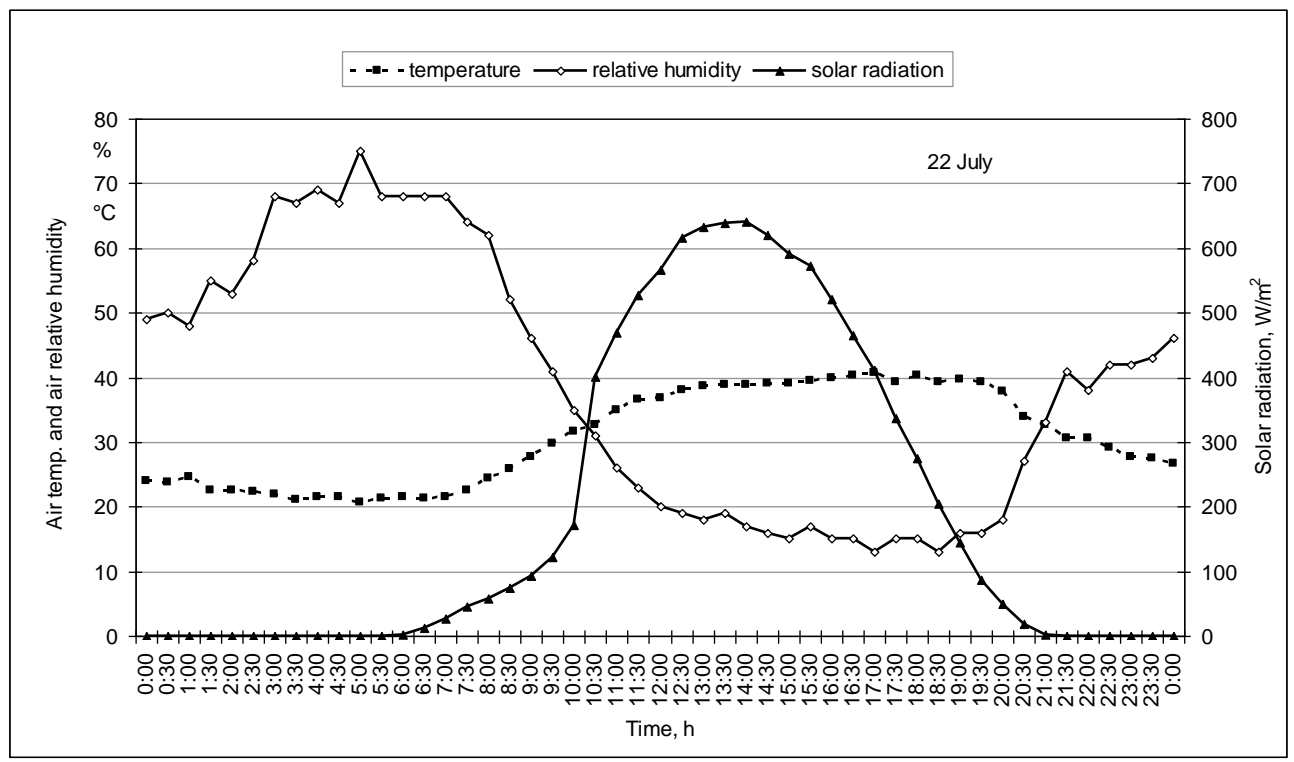

Fig. 5: The air temperature, air relative humidity and solar radiation during the period of experiments (22 July) 


\section{Drying conditions:}

The collected data were analyzed to investigate and test the drying process of squash under both ambient and heated air conditions. The effects of slices thickness and drying air conditions on moisture removal rate, the moisture content and the chemical analysis for dried squash were also investigated against drying time. During drying process of $0.5 \mathrm{~cm}$ thick squash slices the lowest ambient air temperature was $30{ }^{\circ} \mathrm{C}$ at 9 am and the highest ambient temperature was $45{ }^{\circ} \mathrm{C}$ at $4 \mathrm{pm}$. Whereas, the lowest and highest drying air temperatures were $35{ }^{\circ} \mathrm{C}$ and $70{ }^{\circ} \mathrm{C}$ at 9 am and $2 \mathrm{pm}$, respectively. Same data were obtained during the drying process of $1 \mathrm{~cm}$ thick squash slices as illustrated in Figs. 6 and 7.

\section{Moisture removal rate and moisture content:}

The effects of slices thickness and drying air conditions on moisture removal and the moisture content were investigated against drying time. The collected data were analyzed to examine the drying process of squash under both 0.5 and $1 \mathrm{~cm}$ slices thickness. The moisture removal rate was high at the first two and three hours for slices 1 and $0.5 \mathrm{~cm}$ thickness, respectively, as compared with any period during the drying process as shown in Fig. 8. It decreased until it reached its minimum value at the end of the drying process. Fig. 9 illustrates the relation between the drying time and the moisture content. The moisture content decreased with time for both treatments. In the first three hours, the initial moisture content was ranged from 90 to $95 \%$ for both treatments. During the first six hours the moisture content decreased rapidly until reach to its minimum value at the end of the drying process.

\section{Chemical analysis before and after drying:}

The chemical analysis before drying (fresh) is compared with the chemical analysis after drying. Total solid soluble (TSS) was high under both 0.5 and $1 \mathrm{~cm}$ slices dried squash as compared with fresh one. The TSS in $0.5 \mathrm{~cm}$ slices thickness was higher than that in $1 \mathrm{~cm}$ slices thickness. On the other hand, the moisture content was high in fresh vegetable as compared with dried one. In $0.5 \mathrm{~cm}$ slices thickness, it was lower than that in $1 \mathrm{~cm}$ slices thickness as indicated in Table 3. In respect of other components like N, P and K it's clear that no more difference between its values before and after drying. 


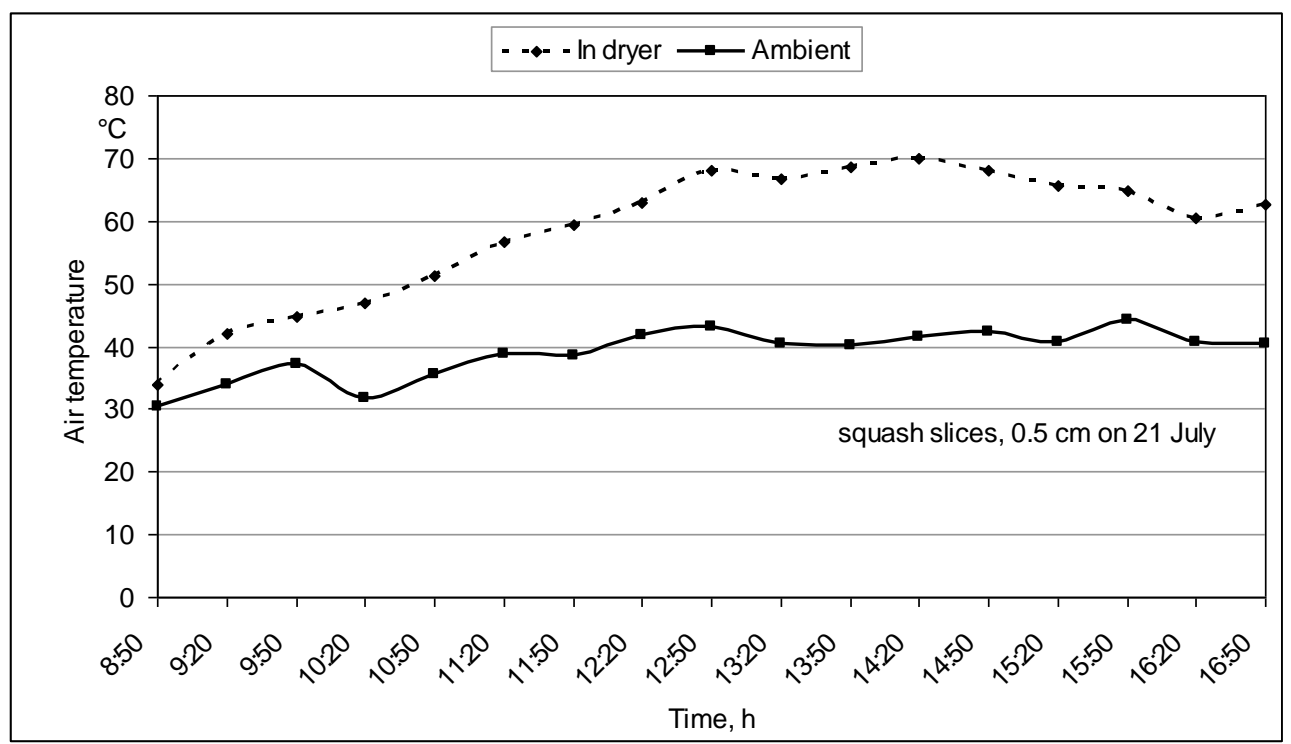

Fig. 6: The relationship between ambient and dryer air temperature for squash slices $0.5 \mathrm{~cm}$ thick

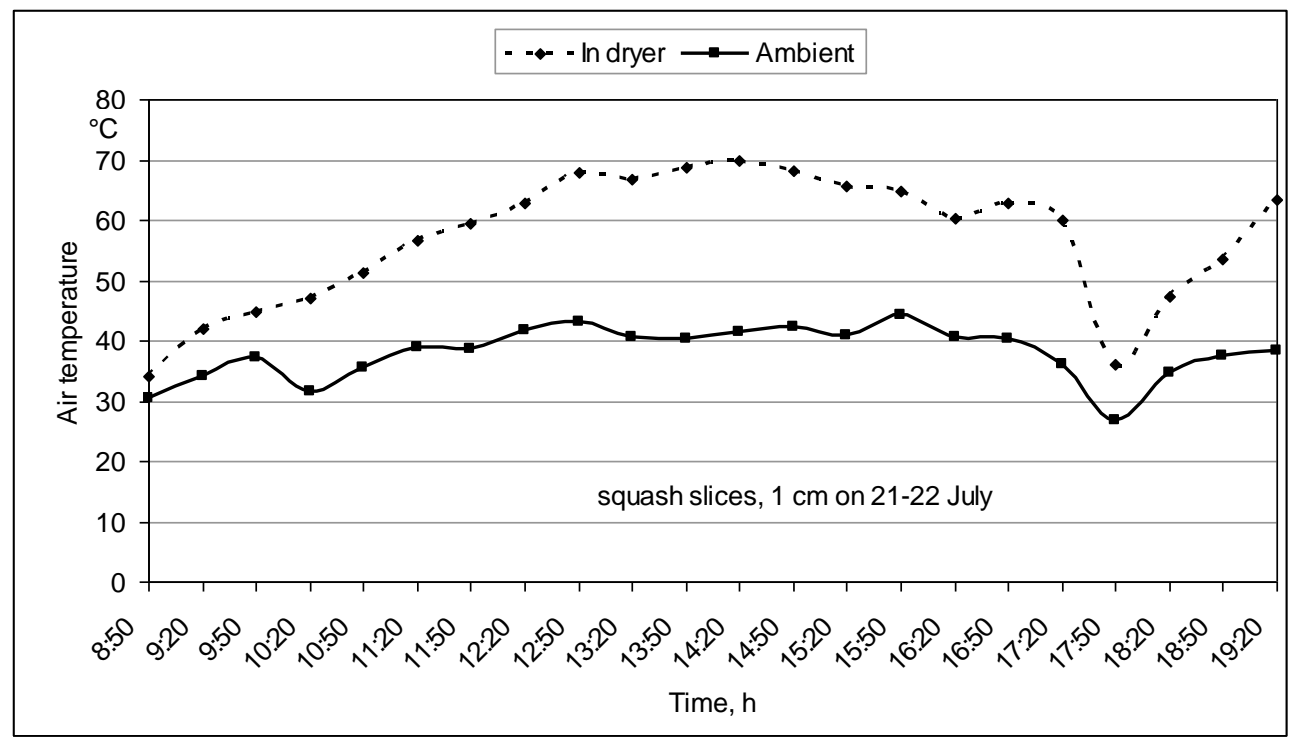

Fig. 7: The relationship between ambient and dryer air temperature for squash slices $1 \mathrm{~cm}$ thick 


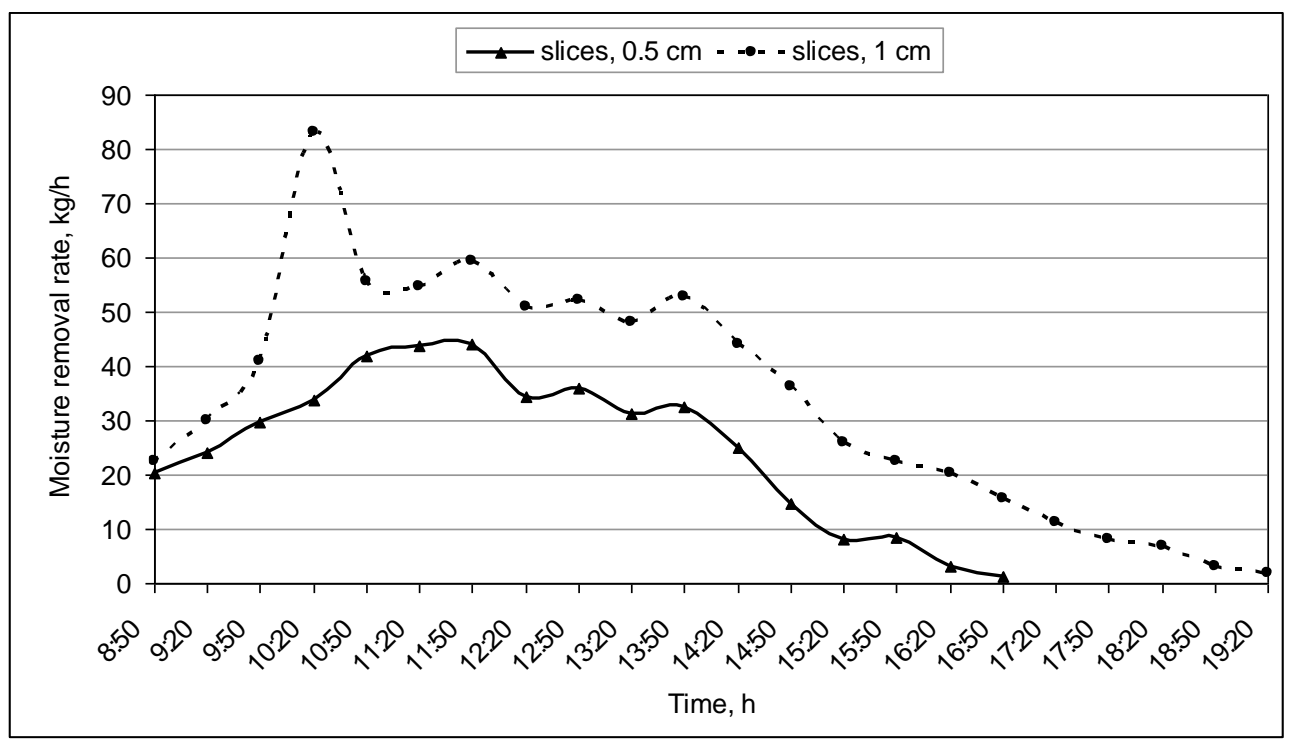

Fig. 8: The relationship between drying time and moisture removal rate with different slices thick

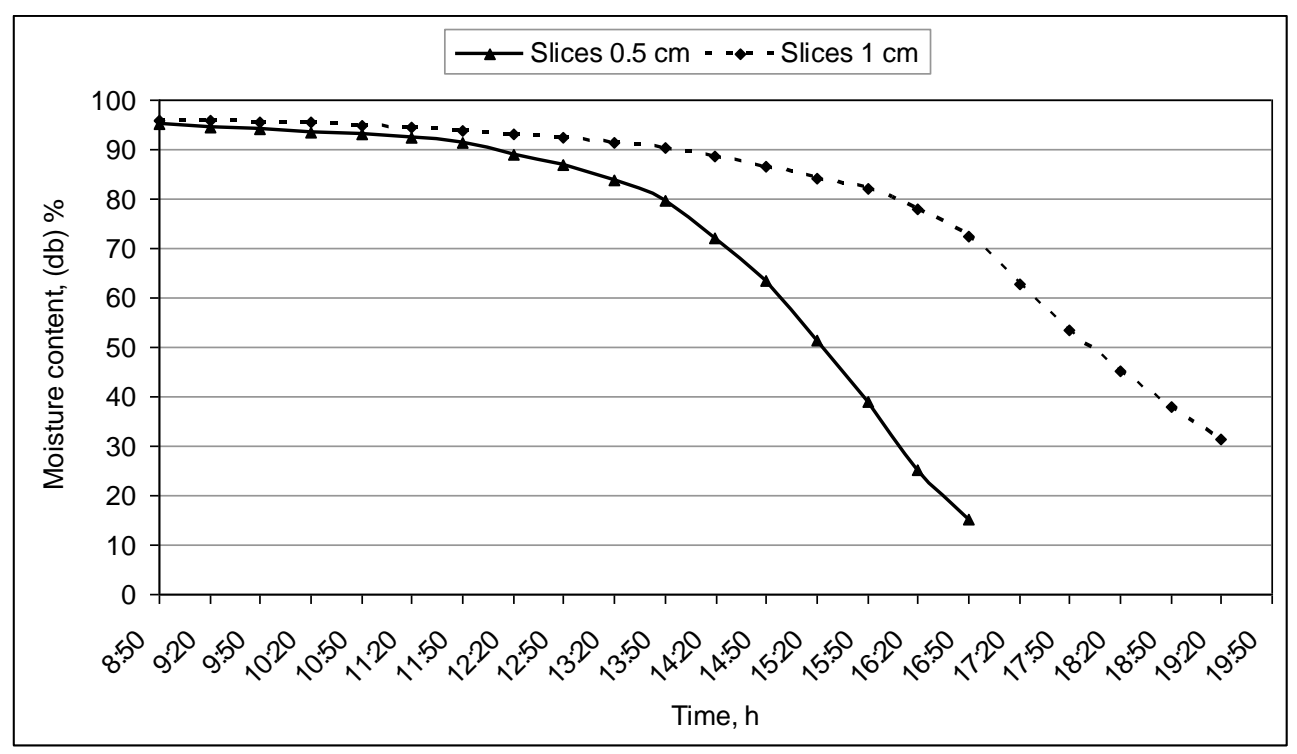

Fig. 9: The effect of drying time on moisture content of different squash slices thick 
Table 3: Chemical analysis for squash before and after drying

\begin{tabular}{|c|c|c|c|c|c|c|c|}
\hline Yield & $\begin{array}{c}\mathrm{N} \\
\%\end{array}$ & $\begin{array}{c}\mathrm{P} \\
\%\end{array}$ & $\begin{array}{c}\mathrm{K} \\
\%\end{array}$ & $\begin{array}{c}\mathrm{CaO} \\
\%\end{array}$ & $\begin{array}{c}\mathrm{MgO} \\
\%\end{array}$ & $\begin{array}{c}\mathrm{TSS} \\
\%\end{array}$ & $\begin{array}{c}\text { Moisture } \\
\text { content } \\
\%\end{array}$ \\
\hline $\begin{array}{c}\text { Fresh } \\
\text { squash }\end{array}$ & 3.9010 & 0.8600 & 2.75 & 0.065 & 0.010 & 4.80 & 95.20 \\
\hline $\begin{array}{c}\text { Dried } \\
\text { squash } \\
0.5 \mathrm{~cm} \\
\text { (slices) }\end{array}$ & 3.3558 & 0.5882 & 2.80 & 0.075 & 0.025 & 84.64 & 15.36 \\
\hline $\begin{array}{c}\text { Dried } \\
\text { squash } \\
1 \mathrm{~cm} \\
\text { (slices) }\end{array}$ & 3.4404 & 1.3667 & 2.65 & 0.070 & 0.015 & 68.48 & 31.52 \\
\hline
\end{tabular}

\section{CONCLUSION}

From the previous results, it can be concluded that:

-There is an inversely relation between the air temperature and air relative humidity. Whereas, the air relative humidity was decreased from $30 \%$ to $15 \%$ as the air temperature increased from $30{ }^{\circ} \mathrm{C}$ to $40{ }^{\circ} \mathrm{C}$.

-There is an inversely relation between the solar radiation and air relative humidity. Whereas, the air relative humidity was decreased from $30 \%$ to $15 \%$ as the solar radiation increased from $300 \mathrm{~W} / \mathrm{m}^{2}$ to $700 \mathrm{~W} / \mathrm{m}^{2}$.

-The maximum difference between air temperature and ambient temperature was $30{ }^{\circ} \mathrm{C}$ at $14.20 \mathrm{~h}$ in both $0.5 \mathrm{~cm}$ and $1 \mathrm{~cm}$ slices thickness of dried squash.

-The higher rate of moisture removal was $80 \mathrm{~kg} / \mathrm{h}$ in $1 \mathrm{~cm}$ thick at the first two hours. While, it was $45 \mathrm{~kg} / \mathrm{h}$ in $0.5 \mathrm{~cm}$ slices in the first three hours.

-In $1 \mathrm{~cm}$ slices, the moisture content reached to $30 \%$ after $11 \mathrm{~h}$ from the beginning of drying time. But it reached to $15 \%$ after $8 \mathrm{~h}$ from the beginning of drying in $0.5 \mathrm{~cm}$ thick. 
-The potassium and phosphor ratios increased in $0.5 \mathrm{~cm}$ and $1 \mathrm{~cm}$ slices thickness. Whereas, the nitrogen ratio decreased in both $0.5 \mathrm{~cm}$ and $1 \mathrm{~cm}$ slices thickness and the minimum value occurred in $0.5 \mathrm{~cm}$ thick.

-The greater total solid soluble was $84.64 \%$ in $0.5 \mathrm{~cm}$ dried slices thickness. Using squash $0.5 \mathrm{~cm}$ slices in drying process may be recommended during the drying process.

\section{REFERANCES}

Adam, E. 1998: Solar Drying of Sliced Onion and Quality Attributes as Affected by the Drying Process and Storage Conditions. Dissertation, Forschungsbericht Agrartechnik des Arbeitskreises Forschung und Lehre der Max-Eyth- Gesellschaft Agrartechnik im VDI, nr. 328, Hohenheim, Germany.

Esper, A. and W. Mühlbauer 1993: Development and dissemination of solar tunnel dryers. Proceedings of Expert Workshop on Drying and Conservation with Solar Energy, p. 63-74, Budapest, Hungary.

Esper, A.; O. Hensel and W. Mühlbauer 1994: PV-Driven Solar Tunnel Dryer. Agricultural Engineering Conference, Bangkok, December 6-9.

FAO, 2006: http://faostat.fao.org

Häuser, M. 1995: Trocknung von Aprikosen mit Solarenergie. Dissertation. Forschungsbericht Agrartechnik des Arbeitskreises Forschung und Lehre der Max-Eyth-Gesellschaft Agrartechnik im VDI. No. 273, Hohenheim, Germany.

Linchk, G. 1993: Thermodynamische Optiemierung von Luftkollektoren für solare Trocknungsanlage. Dissertation, Forschungsbericht Agrartechnik des Arbeitskreises Forschung und Lehre der MaxEyth- Gesellschaft (MEG), nr. 207, Hohenheim, Germany.

Lutz, K. and W. Mühlbauer 1988: Solare Trocknung landwirtschaftlicher Erzeugnisse. Entwicklung und ländlicher Raum, vol 22(6):9-12.

Mitroi, A.; A. Udroiu and C. Iacomi 2000: Utilizarea in Romania a uscatorului solar de tip tunel pentru produse agricole. Revista Mecanizarea Agriculturii, nr. 6, p.19-22.

Reuss, M. 1993: Solar drying in Europe-Proceedings of expert workshop on drying and conservation with solar energy, p. 89-110, Technical University of Budapest, Hungary. 
Udroiu, N. A. 2002: Solare Trocknung von Pflaumen in Rumänien. Teza de doctorat, USAMV-Bucuresti, Romania.

\section{الملخص العربي}

\section{تجفيف الكوسة بإستخدام مجفف أنفاق شمسي مع خلايا كهروضوئية}

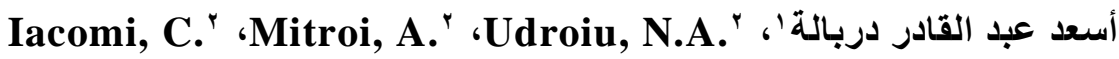

تم إنشاء مجفف تجريبي (نموذج هو هنهايم الألماني) لتجفيف الخضر و الفاكهة وذللك بجامعة العلوم

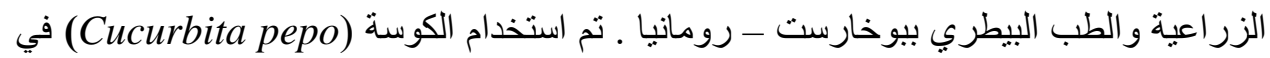

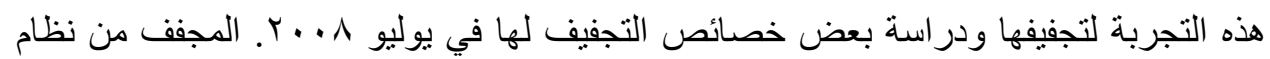
الأنفاق (Tunnels) ويستخدم الخلايا الثمسية (Solar Photovoltaic) كمصدر للنيانية وخلصت النتائج إلي التالي:- ولفئ

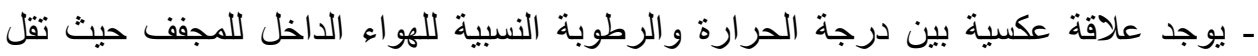

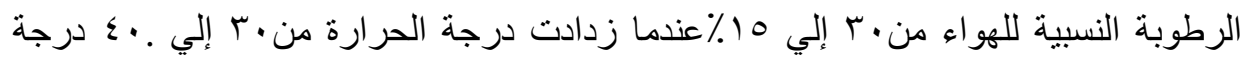

$$
\text { مئوية. }
$$

- يوجد علاقة عكسية بين الإشعاع الشمسي والرطوبة النسبية للهو اء الداخل للمجفف حيث تقل

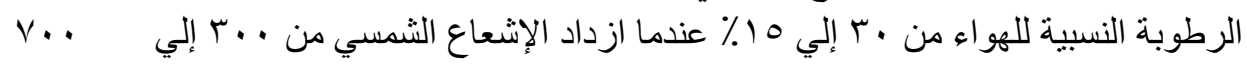

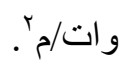

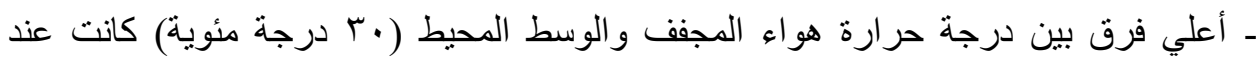

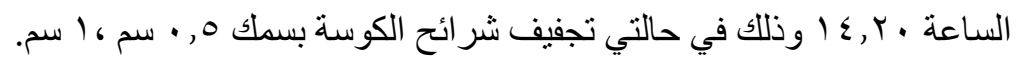

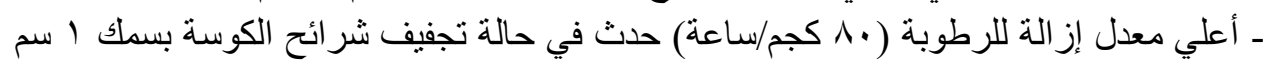

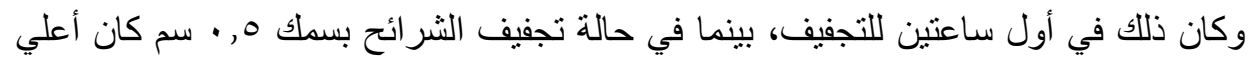

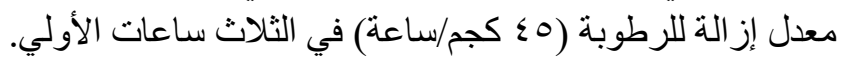

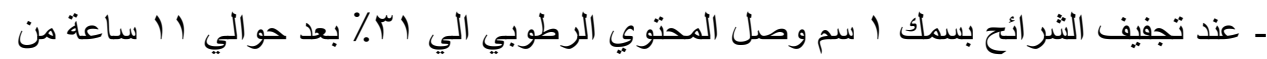

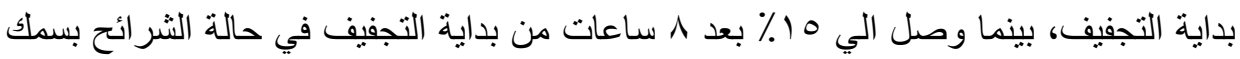

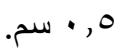

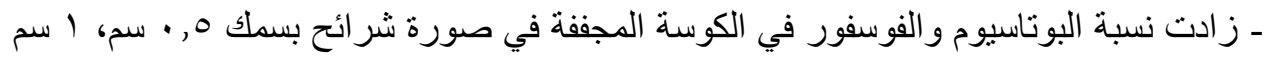

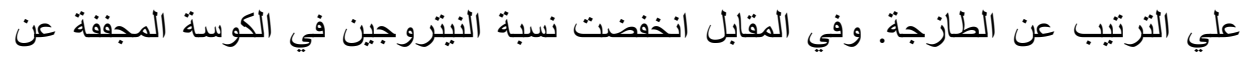

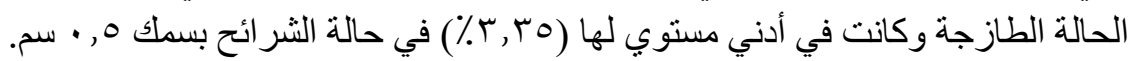

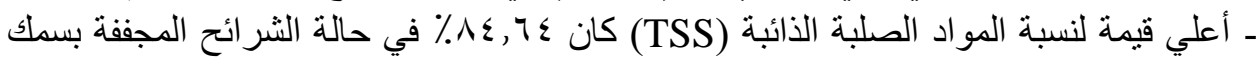

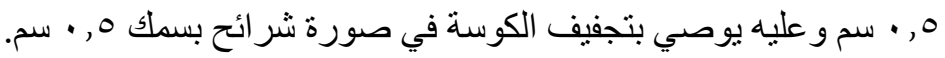

1) - الهندسة الزر اعية - كلية الزر اعة - جامعة طنطا - مصر.

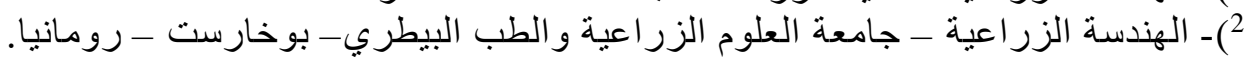

